\title{
Motivation and Job Performance of Academic Staff of State Universities in Nigeria: The Case of Ibrahim Badamasi Babangida University, Lapai, Niger State
}

\author{
Dauda Abdulsalam ${ }^{1} \&$ Mohammed Abubakar Mawoli ${ }^{2}$ \\ ${ }^{1}$ Department of Business Administration, Usman Danfodiyo University, Sokoto, Nigeria \\ ${ }^{2}$ Department of Business Administration, Ibrahim Badamasi Babangida University, Lapai, Nigeria \\ Correspondence: Dauda Abdulsalam, Department of Business Administration, Usman Danfodiyo University, \\ Sokoto, Nigeria. Tel: 234-803-5073-549. E-mail: daomoyi@yahoo.co.uk
}

Received: March 13, 2012 Accepted: May 21, 2012 Online Published: July 16, 2012

doi:10.5539/ijbm.v7n14p142 URL: http://dx.doi.org/10.5539/ijbm.v7n14p142

\begin{abstract}
This study investigates the relationship between motivation and teaching performance on one hand, and motivation and research performance on the other hand. It employs a survey research method in collecting data from academic staff of Ibrahim Badamasi Babangida University, Lapai (IBBUL), Nigeria. A total of 141 or $64 \%$ of the academic staff of the University were sampled out of a population of 219 academic staff. Pearson correlation and linear regression statistical tools were used to determine the relationship as well as the effect of motivation on both teaching and research performances. The result reveals a moderate positive correlation between motivation and teaching performance; and a weak negative correlation between motivation and research performance. It further shows that motivation exerts significant influence on teaching performance but does not exert any significant influence on research performance. The study therefore recommends that universities should take the issue of academic staff motivation seriously to facilitate effective teaching and delivery of knowledge. Universities should also set aside special funds for sponsoring publication and even marketing of researches conducted by the academic staff.
\end{abstract}

Keywords: motivation, research performance, teaching performance, academic staff, university

\section{Introduction}

Universities the world over, have the prime objectives of impacting knowledge through teaching, research and community services. To effectively deliver on these objectives, qualified and competent academics are harnessed. However, the performance of academic staff is not only a function of ability (qualification and competence) but also of motivation. Ngu (1998) contends that the two most important variables explaining employee performance are motivation and ability. Ngu (1998) also defines motivation as the enthusiasm and persistence with which a person does a task, while ability refers to task competence. Impliedly therefore, academic staff can only reach peak performance if they are adequately motivated assuming that the issue of competence is taken as given.

Effective job performance by the academic staff can lead to the realization of the broad objectives for which universities are established, namely knowledge delivery, research and community services. Blanchard (2004) affirms that good performance in higher education will lead to positive growth. For example, effective knowledge delivery will facilitate skill acquisition and entrepreneurship development which will bring about poverty reduction especially in developing countries one of which is Nigeria. Abundant research output will expand the frontiers of knowledge and accelerate social, economic, artistic, scientific and technological development in every society. Abdulkareem and Oyeniran (2011) corroborate that universities are established to serve as centres of technological and scientific advancement, skills development, production of quality entrepreneurial graduates, and strategic researches and development strategies.

\subsection{Statement of the Problem}

There is a general conceptualization that motivation is a correlate of job performance. In particular, Nelson and Quick (2003) contend that that a job high in motivation and hygiene factors leads to high performance and few complaints among employees. This supposition is, to the best knowledge of the researchers, yet to be verified 
and supported empirically. Previous studies that found positive correlation between motivation and job performance adopted motivational model/scales other than that of Herzberg's, and the studies were conducted in industries other than educational industry in Nigeria (see for example, Abejirinde, 2009; Baibaita, 2010; Geofrey, 2010; and Akanbi, 2011). Therefore, the problem of the study expressed in a question form is: how does employee motivation affect employees' job performance in Nigerian universities? This is the gap that the current study intends to fill.

\subsection{Objectives of the Study}

The broad objective of the study is to empirically examine the effect of employee motivation on the job performance of academic staff. In line with the broad objective of the study, the following specific objectives shall be achieved:

i. To determine the effect of academic staff motivation on their teaching performance;

ii. To ascertain the effect of academic staff motivation on their research performance;

iii. To examine the relationship between academic staff motivation and their overall job performance.

\section{Literature Review}

A plethora of writers in the literature subscribe to the fact that motivation is goal directed behaviour which involves individual forces (internal and external) that account for the direction, level, and persistence of a person's effort expended at work, (Nelson and Quick, 2003; Luthans 1998; and Pinder 1998). Motivation can be induced by the employer or reside within the employee. So, identifying motivation is considered essential to understanding why some employees work hard and some do not.

In the same vein, some scholars believe that performance is behaviour exhibited or something done by the employee (Campbell, 1990). So, job performance is not a single unified construct but a multidimensional construct consisting of more than one kind of behaviour. Campbell (1990) used eight-factor model of performance to capture dimensions of job performance behaviour across all jobs: Task specific behaviours; Non-task specific behaviour; Written and oral communication tasks; Effort; Personal discipline; The degree to which a person helps out the groups and his or her colleagues; Supervisory or leadership; and Managerial and administrative performance.

So, from the context of the relationship between motivation and performance, the notion that employees who are highly motivated are much more likely to be high performers is widespread in management and organizational psychology literature. Lawler (1994) and Buchanan and Huczynski (1997) submit that motivation is the single most important determinant of individual job performance. According to Nelson and Quick (2003), motivation factors lead to positive mental health and challenge people to grow, contribute to the work environment and invest themselves in the organization.

Empirical investigations by Brownell and McInnes (1986) revealed that managers who are highly motivated are much more likely to be high performers. Also, Emmanuel, Kominis and Slapnicar (2008) investigation on the relationship between managerial motivation and performance confirmed earlier findings - managers who experience high levels of motivation are also likely to exhibit high job performance. Abejirinde (2009) investigated the relationship between motivation and work performance within private and public enterprises in Nigeria and found that promotion (as a motivator) and employees' performance are positively correlated. It was also revealed that job growth (as a motivator) has significant relationship with employees performance. Another study by Baibaita (2010) revealed that motivation exerts positive impact on the employees' performance in the Nigerian banking industry. Corroborating earlier findings, Mitchell (1982) opines that majority of studies in the field of organizational psychology conclusively demonstrate that individuals who are highly motivated tend to be highly performing.

Geofrey (2010) conducted a study which investigated public universities' academic staff performance with reference to the context of motivation using Makerere University in Uganda as a case study. It examined the effect of motivational factors on lectures' teaching, research activities, and community service. The findings revealed that, motivational factors, significantly affected lecturers teaching and research activities at Makerere University. It also found out that motivational factors did not have significant effect on lecturers' community service activities. It was concluded that, motivational factors do have a significant effect on lecturers' teaching and research activities.

\section{Methodology}

The study is based on a single case study conducted in a state government owned university, Ibrahim Badamasi 
Babangida University, Lapai in 2010. The great strength of a case study method is that it allows the researcher to concentrate on a specific instance or situation and to identify, or attempt to identify, the various interactive at work (Bell, 2004). Thus, Nisbet and Watt (1980) affirm that sometime it is only by taking a practical instance that we can obtain a full picture of this interaction.

The study adopted a survey research method, which according to Cooper and Schindler (2003) involves surveying people and recording their responses for analysis. Hair, Bush and Ortinau (2000) describe a survey as a procedure for collecting large amounts of raw data using interviews or questionnaire. Thus, the justification for the adoption of this instrument is hinged on its ability to generate the required data from the sampled staff for analysis. It is also adopted because the researchers do not intend to manipulate any of the variables under study.

At the time of the study, the University had 15 departments and 219 members of academic staff. Using Guilford and Flruchter (1973)'s formula for estimating sample size, the study sample size was put at 141 which represents $64 \%$ of the population (see appendix 1). Hence, $64 \%$ of the academic staff were proportionately selected from each department of the university to form the study sample. Peretomde (1992) and Owojori (2002) maintain that a sample size that is not less than $10 \%$ of the study population is a good representative of the population.

All data relating to the research explanatory variables, namely motivation, teaching performance, and research performance were collected and evaluated using nominal scale - the 5-point Likert type rating scale. The motivation scale is made up of 6 items, teaching performance scale (10 items), and research performance scale (12 items). Both teaching and research performance scales were subsequently aggregated to represent $j o b$ performance scale. The reliability of the three scales was tested using Cronbach Alpha.

The completed copies of questionnaire were retrieved from the respondents and subsequently analyzed. A total of 110 or $78 \%$ of the distributed copies of questionnaire were retrieved. The responses were evaluated and used to generate an index of motivation, teaching performance and research performance which were used to process inferential statistics (correlation and linear regression). The index of motivation was used as the independent variable, while the index of teaching and research performance were used as the dependent variables.

The following null hypotheses were used to examine the relationship that exists between the variables;

$\mathrm{H}_{01}$ : There is no significant relationship between motivation and teaching performance.

$\mathrm{H}_{02}$ : There is no significant relationship between motivation and research performance.

$\mathrm{H}_{03}$ : There is no significant relationship between motivation and job performance.

Specifically, both Pearson correlation and linear regression statistical techniques were employed to test the hypotheses. All statistical tests were at 95 percent confidence level. Statistical Package for Social Sciences Version 17 (SPSS V. 17) and Microsoft Excel were used to effect the analysis of data.

\subsection{The Model}

The study model is mathematically expressed as follows:

$$
\text { Per }=f(\text { Mot })
$$

Equation 1 was further expanded as follows:

$$
\text { RPer }+ \text { TPer }=f(\text { Mot })
$$

Where: Per $=$ Performance

$$
\begin{aligned}
& \text { Mot }=\text { Motivation } \\
& \text { RPer }=\text { Research Performance } \\
& \text { TPerf = Teaching Performance }
\end{aligned}
$$

The mathematical model above is represented diagrammatically in figure 1 and 2 below. 


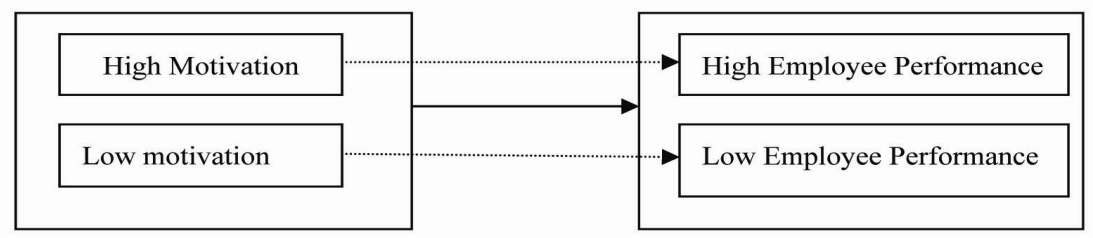

Figure 1. Relationship between motivation and performance

Source: Author's Conceptualization (2010)

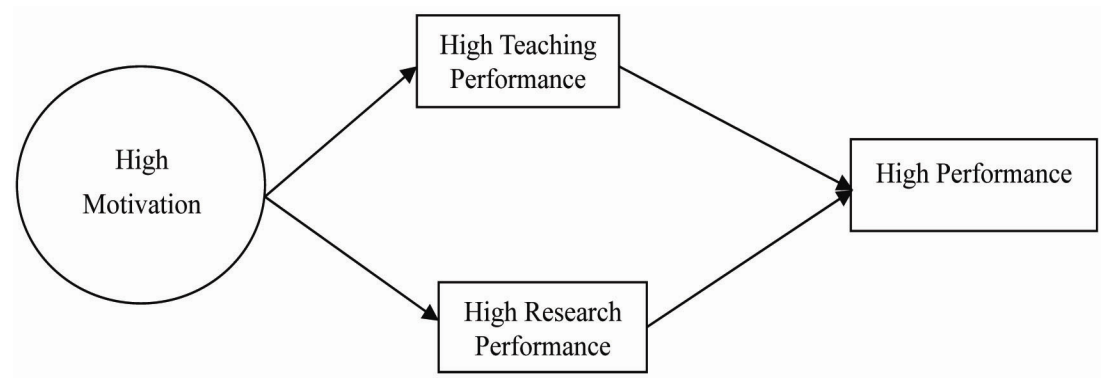

Figure 2. Relationship between motivation and (1) teaching performance and (2) research performance Source: Researcher's Conceptualization (2010)

Subsequently, the model was quantitatively captured and tested using the following linear regression model:

Per $=\beta_{0}+\beta_{1} M o t+e$

Where: Per $=$ performance (the dependent variable).

$\beta 0=$ constant or intercept term.

$\beta_{1}=$ the coefficient of academic staff motivation

Mot $=$ Motivation (the independent variable)

$\mathrm{e}=$ error term.

\section{Results}

\subsection{Reliability Test}

The reliability of the scales was determined using Cronbach's alpha method. Analysis revealed that motivation scale is reliable by $64 \%$, teaching performance by $76 \%$, research performance by $89 \%$, and total performance by $88 \%$ (see table 1). Cronbach's alpha measures the average of measurable items and its correlation, and if the result is generally above 0.5 (or 50\%), it is considered to be reliable (see Peighambari, 2007).

Table 1. Reliability coefficients of the research variables

\begin{tabular}{lcc}
\hline \multicolumn{1}{c}{ Factor } & Number of items & Cronbach Alpha \\
\hline Motivation & 6 & 0.64 \\
Teaching performance & 10 & 0.76 \\
Research performance & 12 & 0.89 \\
Performance & 22 & 0.88 \\
\hline
\end{tabular}

Source: Researchers' Computation, 2010

\subsection{Test of Hypothesis}

\subsubsection{Relationship between Motivation and Teaching Performance}

It was considered pertinent to investigate the relationship between motivation and teaching performance. The 
result of the test of hypothesis was a Pearson correlation coefficient $=0.484$, $\mathrm{df}=1$ which was significant at $\mathrm{P}=.000(\mathrm{P}<.01)$. According to Attar and Swers $(2010)$, values of Pearson correlation lying in the range $(0.1-$ $0.29)$ suggest small correlation, values in the range (0.3-0.49) suggest moderate correlation while values in the range (0.5-1) suggest large correlation between variables. Thus, moderate positive correlation has been established between motivation and teaching performance (see table 2, column 1 in the appendix). In essence, hypothesis one which postulates that there is no significant relationship between motivation and teaching performance is rejected.

Similarly, linear regression analysis shows that there exists moderate relationship between motivation and teaching performance. Specifically, the coefficient of determination $\left(R^{2}\right)=0.234$ indicates the explained variance and shows that $23 \%$ of the variance in the teaching performance has been significantly explained by motivation. In other words, other factors apart from staff motivation would most likely account for $77 \%$ of the variation in academic staff level of teaching performance (see table 2-column 1 below).

Table 2. Summary of pearson correlation and regression results

\begin{tabular}{lccc}
\hline & Colum 1 & Colum 2 & Colum 3 \\
\cline { 2 - 4 } & $\begin{array}{c}\text { Motivation and Teaching } \\
\text { Performance }\end{array}$ & $\begin{array}{c}\text { Motivation and Research } \\
\text { performance }\end{array}$ & $\begin{array}{c}\text { Motivation and } \\
\text { performance }\end{array}$ \\
\hline Pearson correlation & 0.484 & -0.155 & 0.064 \\
R square $\left(\mathrm{R}^{2}\right)$ & 0.234 & 0.024 & 0.004 \\
Beta & 22.481 & 54.082 & 76.563 \\
F-statistics & 16.217 & 1.310 & 0.215 \\
t- test & 4.027 & 1.144 & 0.463 \\
Significance level $(\alpha)$ & 0.000 & 0.258 & 0.645 \\
$\mathrm{~N}=141$ & & &
\end{tabular}

Thus, the analysis of data yielded the regression equation as follows:

$$
\text { Per }=22.481+0.811 x+0.201
$$

The test statistics $\mathrm{t}=4.027 ; \mathrm{df}=1, \mathrm{R}^{2}=0.234$ which was significant at $\mathrm{P}=0.000(\mathrm{P}<0.01)$.

\subsubsection{Relationship between Motivation and Research Performance}

It was considered necessary to investigate the relationship between motivation and research performance. The result of the test of hypothesis was a Pearson correlation coefficient $=-0.484$, and $\mathrm{P}=0.258$. This signifies small negative correlation between motivation and research performance (see table 2-column 2 above). Thus, the research hypothesis two which postulate that there is no significant relationship between motivation and research performance is upheld.

Linear Regression analysis revealed a coefficient of determination $\left(R^{2}\right)=0.024$, which indicates that $2.4 \%$ of the variance in the research performance has been significantly explained by staff motivation. That is, other factors apart from motivation probably account for $97.6 \%$ of the variation in research performance (see table 2-column 2 above).

The analysis of data yielded the regression equation as follows:

$$
\text { Per }=54.082-0.538 x+0.470
$$

The test statistics $\mathrm{t}=-1.144 ; \mathrm{df}=1, \mathrm{R}^{2}=0.24$ which was not significant at $\mathrm{P}=0.258(\mathrm{P}<0.05)$.

\subsubsection{Relationship between Motivation and Performance}

An attempt to investigate the relationship between motivation and performance revealed a Pearson correlation coefficient $=0.064$, and $\mathrm{P}=0.645$. This signifies weak positive correlation between motivation and research performance (see table 2-column 3 above). Thus, the research hypothesis three which postulate that there is no significant relation relationship between motivation and performance is supported.

Linear Regression analysis revealed a coefficient of determination $\left(\mathrm{R}^{2}\right)=0.004$, which indicates that $0.4 \%$ of the variance in the research performance has been significantly explained by staff motivation. That is, other factors apart from motivation probably account for $99.6 \%$ of the variation in staff performance (see table 2-column 3 
above).

The analysis of data yielded the regression equation as follows:

$$
\text { Per }=76.563+0.272 x+0.588
$$

The test statistics $\mathrm{t}=0.463 ; \mathrm{df}=1, \mathrm{R}^{2}=0.004$ which was not significant at $\mathrm{P}=0.645(\mathrm{P}<0.05)$.

\subsection{Discussion of Findings}

Analysis reveals that motivation exerts significant influence on teaching performance. The coefficient of determination $\left(\mathrm{R}^{2}\right)=0.234$ shows that $23 \%$ of the variance in the teaching performance has been significantly explained by motivation. Put differently, other factors apart from staff motivation would most likely account for $77 \%$ of the variation in academic staff level of teaching performance. This finding concurs with the findings of Geofrey (2010) in Makerere University, where it was observed that motivational factors have a significant effect on lecturers' teaching and research activities. This entails that the more staff are motivated, the more they are likely to attend to their classes, exhaust the lesson periods, read and correct students' assignments and projects among others thereby ensuring the attainment of the University and national goal which is 'quality education to students. Studies conducted by Stevens and White (1987) show that improvement in teacher motivation has benefits for students and teachers. In Nigeria, the quality of education at all levels (primary school, secondary school and tertiary institutions) has long been adjudged as substandard, half-baked, and poor while the causes have been attributed to poor funding, overpopulation of students, inadequate and outdated infrastructures, and above all, poor remuneration and motivation of the academic staff (see: Mafiana, 2011; Ekundayo, and Ajayi, 2009; and Akinsanya, 2007). In essence, staff motivation being a strong determinant of staff contribution to teaching can be used as a weapon to reverse the declining standard of university education in the country.

The study also reveals that staff motivation does not affect the academic staff research performance. The Pearson correlation coefficient is -0.484 , and $\mathrm{P}=0.258$. This signifies small negative correlation between motivation and research performance. This is despite the fact that research is sine qua non for staff promotion and trumpeted in the academy as "publish or perish." Given the fact that carrying out effective teaching by staff does not necessarily require expending personal cash but only effort, while in the case of research or publications such expenditure is unavoidable as the individual staff bears the entire financial responsibilities for research and publication. Hence, lecturers needs to be given financial, logistic and technical support by their universities to enable them turnout optimal number of researches needed for economic, administrative, social, and technological development.

\section{Conclusions and Recommendations}

It was predicted that staff motivation could impact on academic staff teaching performance as well as research performance. It was, however, found that motivation exerts significant impact on academic staff teaching performance but does not wield significant influence on academic staff' research performance. Impliedly, university lecturers must be adequately motivated to facilitate effective knowledge delivery to students, uplift standard of education and solve the lingering problem of declining standard of education in the country. Furthermore, staff motivation alone cannot bring about increase in academic research except if such (i.e. research projects) are fully or partly financed by the university. Hence, the study recommends that:

1) Universities and other tertiary institutions should take the issue of academic staff motivation seriously to facilitate effective teaching and delivery of knowledge;

2) Universities should set aside special funds for sponsoring publication and even marketing of researches conducted by the lecturers.

\subsection{Suggestion for Further Study}

Being a survey research, this study is most likely to provoke some other studies as a follow up in a bid to establish the likely effect of academic staff motivation on performance. Specifically, to enhance the prospect of generalizing the findings of the current study, it is necessary to expand the scope in terms of the sample size and the selection strategy. It is therefore suggested that the study be replicated by using a much larger sample selected more broadly from public and/or private universities in Nigeria.

\section{References}

Abdulkareem, A. Y., \& Oyeniran, S. (2011). Managing the Performance of Nigerian Universities for Sustainable Development Using Data Environment Analysis. llorin Journal of Sociology, 3(1), 37-50.

Abejirinde, A. A. (2009). Motivation and Workers Performance within Public and Private Enterprises in Nigeria. 
Lapai International Journal of Management and Social Sciences, 2(2), 101-112.

Akanbi, P. A. (2011). Influence of extrinsic and intrinsic motivation on employee's performance. Retrieved from http://www.ilo.org/public/English/iira/documents/congresses/regional/lagosdoll/3rdparallelsession3b/motiva tionalworker.pdf

Akinsanya, O. O. (2007). Financing Higher Education in Nigeria. Retrieved from https://ojcs.siue.edu/ojs/index.php/ijaaas/article/viewFile/91/151

Babaita, I. S. (2010). An Appraisal of Employee Motivation in the Nigerian Banking Industry. Lapai Journal of Management Sciences, 1(1), 25-39.

Bell, J. (2004). Doing Your Research Project: A Guide for First-time Researchers in Education and Social Science (3rd ed.). New York: McGraw-Hill House.

Blanchard, O. (2004). Economic Future of Europe. NBER Working Paper, 103(10).

Brownell, P., \& McInnes, M. (1986), Budgetary Participation, Motivation and Managerial Performance. The Accounting Review, 61(4), 587-600.

Buchanan, D., \& Huczynski, A. (1997). Organizational Behaviour: An Introductory Text (3rd ed.). London: Prentice Hall.

Campbell, J. P. (1990). Modeling the Performance Prediction Problem in Industrial and Organizational Psychology. In M. D. Dunnette \& L. M. Hough (Eds.), Handbook of Industrial and Organizational Psychology, 687-732.

Cooper, D. R., \& Schindler, P. S. (2003). Business Research Methods (8th ed.). New-York: McGraw-Hill.

Ekundayo, H. T., \& Ajayi, I. A. (2009). Towards Effective Management of University Education in Nigeria. International NGO Journal, 4(8), 343-347.

Geofrey, Y. (2010). Motivation and Academic Staff Performance in Public Universities in Uganda: The Case of Makerere University. Retrieved from http://dspace.mak.ac.ug/handle/123456789/1339

Guilford \& Flrucher. (1973). Fundamental Statistics in Psychology Education. New York: McGraw-Hill.

Hair, J. F., Bush, R. P., \& Ortinau, D. J. (2000). Marketing Research: A Practical Approach for New Millennium. Singapore: Irwin McGraw-Hill.

Lawler, E. E. (1994). Motivation in Work Organization. San Francisco: Jossey-Bass Inc.

Luthans, F. (1998). Organizational Performance (8th ed.). Boston: Irwin McGraw-Hill

Mafiana, C. F. (2011). Quality Assurance in University Education. Paper presented in the International Conference on "Issues and Challenges in University Education in the Age of Globalization" between 5-8 December.

Mitchell, T. R. (1982). Motivation: Need Directions for Theory, Research, and Practice. Academy of Management Review, 7(1), 80-88.

Nelson, D. L., \& Quick, J. C. (2003). Organizational behaviour: foundation, realities and challenges (4th ed.). Australia: Thomson South-Western.

Ngu, S. M. (1998). Motivation Theory and Workers Compensation in Nigeria. Zaria: ABU Press.

Nisbet, J., \& Watt, J. (1980). Case Study. Rediguide, 6.

Owojori, A. A. (2002). Managerial Research. Ado-Ekiti: Kaycee Publishers.

Peighambari, K. (2007). Developing and Testing a Model for Explaining Customer Retention Formation. Master Thesis, Tarbiat Modares University. Retrieved from http.luth.se/1653-0182/2007/066/LTU-PB-EX-07066-SE.Pdf.

Peretomode, V. F. (1992). Basic Research Method for Education and Social Sciences. Owerri: Total Publishers Ltd.

Pinder, C. C. (1998). Work Motivation in Organizational Behaviour. Upper Saddle River, New Jersey: Prentice-Hall.

Stevens, R., \& White. W. (1987). Impact of teacher's morale on the classroom. Perceptual and Motor Skills, 65, 787-90. http://dx.doi.org/10.2466/pms.1987.65.3.767 